\title{
The Influence of Renaissance and Religious Reform on the Development of Music and Art Style
}

\author{
Jenny YU \\ No.93 Jingsan Road, Zhengzhou 450000, China \\ Corresponding author Email: 670278757@qq.com
}

Keywords: Renaissance art, Medieval artists, Realism literature, Human spiritual world.

\begin{abstract}
Renaissance art was devoted to the recreation of ancient culture, and there was a kind of realism literature. Medieval artists added the poetry of expressing human spiritual world to the music. During the two periods, the key point of art was shifted to the humanism. This paper presents that the influence of art on human emotion world through the description of the changes from the art before to the art of Renaissance and the middle ages. And art is becoming more and more practical. For contemporary society, all kinds of art forms still exist, they also can enrich human emotion world, and make the society rich and colorful.
\end{abstract}

\section{Introduction}

The Renaissance rose in the 14th century in Italy, and from the late 15th century it gradually extended to the whole of Europe and in the 16th century it reached the height of a magnificent ideological and cultural movement [1,2]. During the Reformation, people just followed the God and Pope. Even if church sold the indulgences, people believed them that indulgences could help them to go the Heaven quickly. At that time, the style of the music was monophony. But when it was the Middle Ages, the style was polyphony [3,4].

During the Medieval, Sacred music and secular music influenced the thinking of people in different aspects to some extent. The traditions of Western music can be traced back to the social and religious developments that took place in Europe during the Middle Ages [5].

The changes about music and art influence the people's worldview [6]. The changes in styles of music and art reflect the shift in people's worldview during the Renaissance and Reformation illustrated that European society not only paid attention to Sacred Culture, but also developed the humanism.

\section{The Art of Renaissance}

Most arts during the Medieval were influenced by religion and church. And people believed the God and followed him during the Middle Ages. In the beginning of Middle Ages, the art in Europe was religious art with Catholic subjects and themes. And all of arts were about God. No matter who live at that time, people and artists would believe the God. So artists drew more pictures about religion, church and God. For example, Romanesque art in Middle Ages, like the picture of Fig. 1. This picture described that people followed the God, and God was the center of people. They loved and believed God. There were 12 people and a god in this picture. God's one hand hold the Bible, the other hand pointed at somewhere, like he taught something or say something. And people looked at the God and listened to him. So Romanesque Art focus was on religion and Christianity. The pictures were drawn on the ceiling, 
wall and glasses in church. On the one hand, the picture could make church beautiful; On the other hand, artists wanted to tell people that they should follow the God and God could help them.

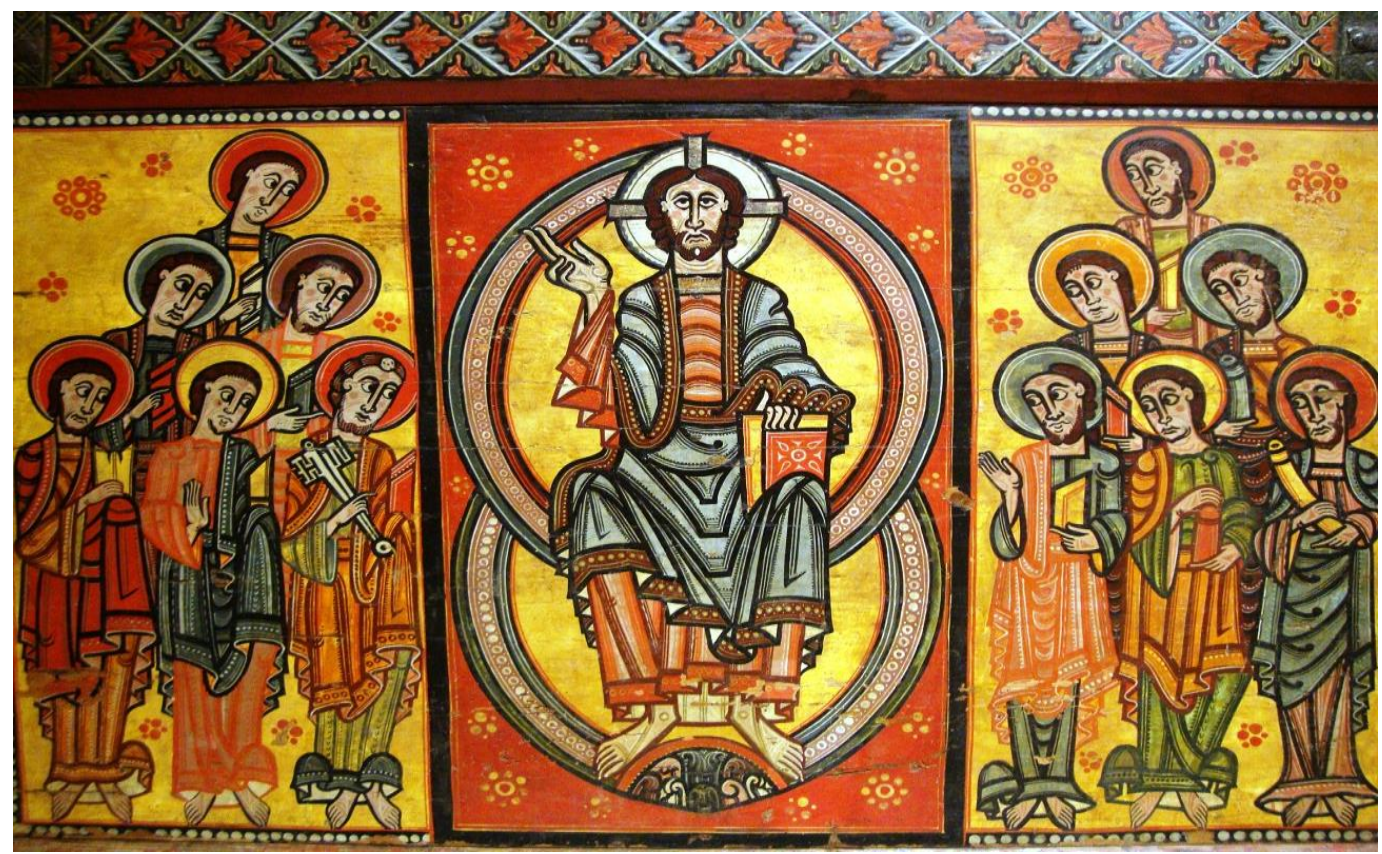

Figure1. People followed the God

Before that, some people did not know who is God. Because they still under the feudal social, people just want to church to do the worship. They did not know what God look like and the purpose of believing God. And then some artists drew something about Christianity to make people know more things about God. And artists told people why people should believe the God though the picture. So people's worldview not only keep on believing the God on the surface, but also people's worldview in that time became that they deeply knew something about God and believed the God.

Artists in the Renaissance started to focus on something about people and real thing, and people no longer just stay in religion. The purpose of humanism is to be the center of all people, and oppose the Church of God as the center of the feudal ideology. With the development of Humanism during the Renaissance, artists' pictures tended to be realistic. They tried to draw some pictures about people's real life and described the emotion of people. For example, like the picture of Fig. 2. There are two people in the room. They were a couple. And the woman was pregnant. It reflected the real life of people and happiness. It made the subjects and background look like they would in real life. They focus on the experience of people, not only they focus on religion. The picture represented marriage, and it is not talk about the God. It also reflected the humanism focus on the people, including life, emotion and relationship. Also, some artist found many pictures about God, and they thought these pictures lacked something about the real life of people. Based on remanding original thoughts, artists started to draw about people's life. So humanism was main thought in the Renaissance. And artists focus on real things. And the people were influenced by pictures. They started to pay attention to real life and people's emotion. So arts in the Renaissance reflected the shift in people's social worldview. 


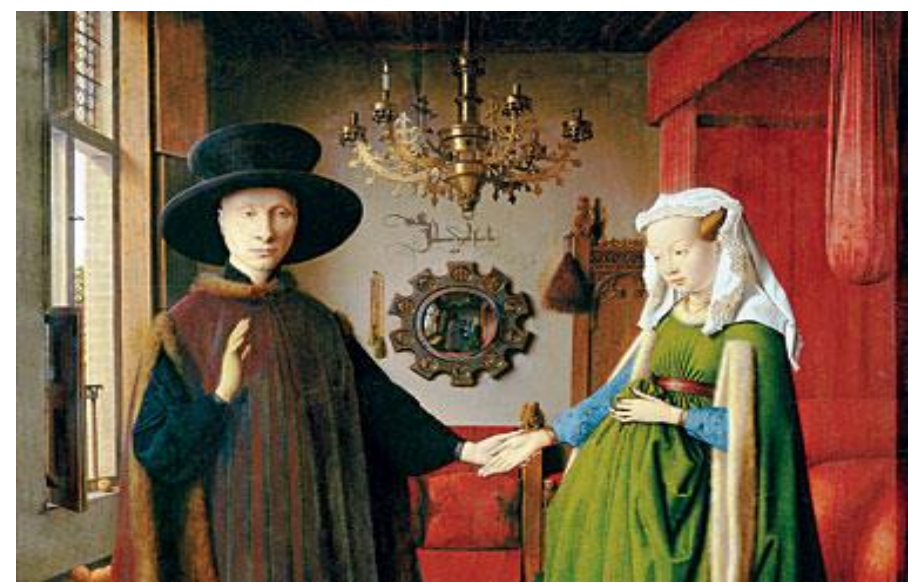

Figure 2. Two people in the room

In the Renaissance, artists focus on art shifted to the human experience. Many of the new ideas and attitudes that marked the Renaissance times were portrayed in art. A new idea called humanism put a focus on human interests, needs, and abilities. This new idea changed how artists painted their subjects as well as the choice of subjects they painted. So artists started to paint human beings. For example, like the picture of Fig. 3. There are many persons. Jesus was sitting in the middle. The picture is famous, because it was not only connect with Jesus, but also describe human's life and experience. The picture told us what the supper look like and what people's emotion. Also the picture was concerned by people, because of artist Da Vinci, perhaps more than any other Renaissance figure, demonstrated the spirit of humanism, excelling in a wide variety of fields and continually seeking to the better himself through knowledge. In fact, the case of Leonardo da Vinci supports the argument that the humanist values of learning, rationality, and reality rose to truly rival and in some cases overshadow the importance of Church doctrines. So at that time, when they concerned Jesus, they also thought about humanism.

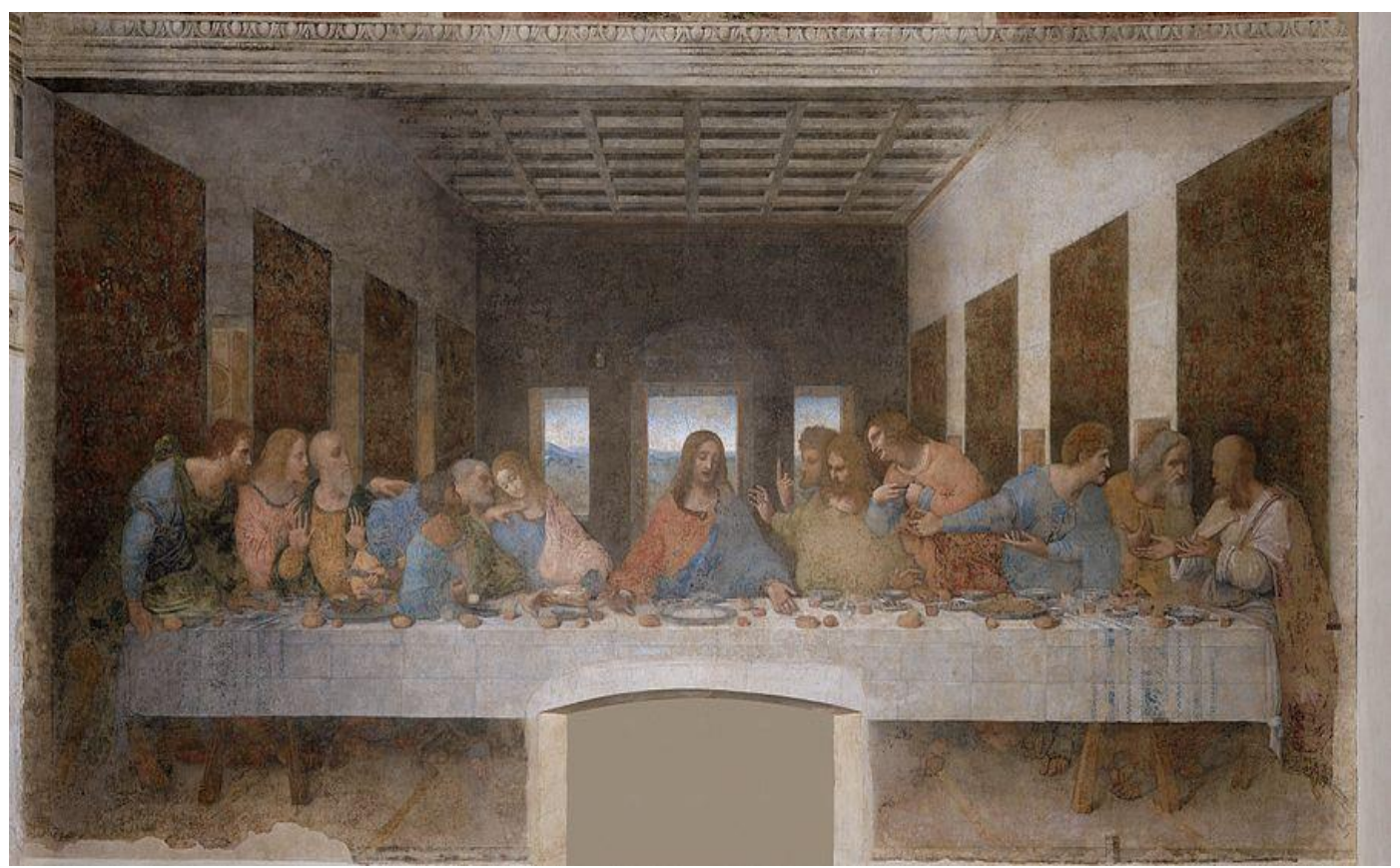

Figure 3. Last Supper 


\section{The art of the Middle Ages}

At the time of the Middle Ages, Christianity was a dominant part of medieval culture, so an entire musical style developed just to support it. So the sacred composers sought to set the Bible to music and to bring a more "heavenly" aspect to church than could be obtained by simply reading the Bible. Sacred music was originally composed to pay homage to God. And Secular music, on the other hand, was composed solely for its entertainment value, whether for dance or to express love. There is the one example, like music of Gregorian Chant - "Salve Regina". The music did not have lyrics. And the music expressed the relationship with God. So it could help people connect with God in Church. And there is the other example, like music of Adam de la Halle - Le jeu de Robin et Marion. Although this music did not have lyrics, it changed the monophony of music. Listen to this music, there are some other instruments. They made music feel richer and more colorful. And a part of the music described the people's life and people's mood. After listening to this, people felt happy. Actually, in Middle Ages, sacred music was influenced people in Church. Many Christians would like to sing songs to connect with God, with Jesus. They wanted to build a good relationship with God. So their worldview was that music just could use on connecting with God, and it could help them to talk with God. Meanwhile, some composers created some music that people can listen to it in their lives. And secular music had the value of entertainment. With the development of secular music, people changed their minds that music also can use on people's lives. So the music in Middle Ages was not only focus on religion and Church, but also focus on human.

The Music became more closed to people's real life. Composers used the polyphony to describe people's life and emotion, and they no longer just use monophony to compose the music. During the Middle Ages, people put focus on sacred music, and the style was monophony. The music just in order to connect the religious, because the music that people sang in the Church. But people thought that the music without lyrics would not to be understood the thought of God, because the music could not be a good expression of people's feelings about God. They needed to use language to communicate with God. So composers created some music with lyrics, and because they were influenced by humanism, the style of music became complex and realistic, like polyphony and dance music. For example, the music of Terpischore created by Michael Praetorius, and it is a piece of dance music. It reflected that people were happy in their life and the emotion of people. The music was played with multiple instruments. It was not like music during the Middle Ages was monophony. Actually, it was more same like improvised. And it also reflected that people paid more attention to humanism and realistic things. They used many different instruments to play music to reflect something realistic and some emotions, like sadness, happiness and indignation. Sometimes they also composed some complex music with polyphony about religion. When they composed the music, they could add some different elements to music, like religion, people's life and emotion. Therefore, people not only know the God through singing the music, but also people could express their emotion about their lives and celebrated something through the music. People's views became more realistic. So music also influenced the people's thought and worldview, it made people had different views to this world.

\section{Discussion}

But now, we need to think about the music and painting at present. Do they influence our worldviews or perspectives? My answer is yes, because different works have 
different meaning. Behind these music and paintings, we can see authors' different perspectives. They show the social thoughts, the phenomenon of society and people's emotion. And these artists and composers pursue the new things, daring and popular. Sometimes artists may draw some pictures to reflect the social worldview, and they influence our perspectives. I think it is more different than the Art during Middle Ages and Renaissance. For instance, in China, Chinese artists always paint a picture in Chinese ink. And many pictures are drawn about people, animals, buildings and plants. Some pictures described people's life and something happened in the ancient. Chinese Brush Painting paid more attention to beauty, mood, nature and simplicity. These pictures are like poem, and people feel comfortable. However, the style of western picture is different from Chinese picture. Most western pictures are oil painting. They pay more attention on color. Like, there are many gradations in color, and they make strong colors. Actually, now, music or art, they are always around us. And they affect our minds. Whenever you are, the changes in style of music and art often can reflect the shift in people's worldview. Because of music and art, the whole society would become more emotional. So now, music and art are more close to realism and Humanism. Although some music is about Christianity, that music is not the same as the music during Middle Ages and Renaissance, because during the that time, music in church was single, and they are not as rich as they are now.

\section{Summary}

In a word, during the Middle Ages and Renaissance, people's minds were no longer just a sacred culture. They were influenced by the art and music, and their worldview was changed. They not only focused on religious, but they started to think about humanism, and they put their thoughts on art and music. This is the change we see. And now, in addition to humanism, music and fine arts have also added to the unique elements and charm of modern. They make the whole society rich and colorful.

\section{References}

[1] L. Davide, G. Luca, The Hand in Art: Clinodactyly in Renaissance Paintings, J. The Journal of Hand Surgery. 40 (2015) 2058-2060.

[2] G. Ciobanu, C. Ungureanu, Visible and invisible structures in Renaissance paintings, J. Materials Today: Proceedings. 2 (2015) 3884-3888.

[3] M. A. Posner, Upper Extremity Replantations in renaissance, J. The Journal of Hand Surgery. 33 (2008) 1440-1441.

[4] E. Howell, Raman spectroscopic study of "The Malatesta": A Renaissance painting?, J. Spectrochimica Acta Part A-Molecular and Biomolecular Spectroscopy. 137 (2015) 45-49.

[5] S. Ramya, R. Conrad, Computerized Face Recognition in Renaissance Portrait Art A quantitative measure for identifying uncertain subjects in ancient portraits, J. IEEE Signal Gnal Processing Magazing. 32 (2015) 85-94.

[6] J. Levy, B. Chant, The new grove dictionary of music and musicians, J. The Journal of Academic Librarianship. 4 (2001) 102-108. 